\title{
Identification of Manganese Distribution Using Very Low Frequency (VLF) Method at Karangsari Village, Pengasih Sub-District, Kulonprogo Regency, DIY
}

\author{
Wulan Listyorini*, Thaqibul Fikri Niyartama, Muhammad Faizal Zakaria \\ Physics Department, Faculty of Science and Technology, UIN Sunan Kalijaga Yogyakarta \\ Jl. Marsda Adisucipto No 1 Yogyakarta 55281, Indonesia. Tel. +62-274-540971, Fax. +62-274-519739. \\ Email: wulanlistyorini0@gmail.com
}

\begin{abstract}
Listyorini W, Niyartama T F, Zakaria M F. 2017. Identification OF Manganese Distribution Using Very Low Frequency (VLF) Method at Karangsari Village, Pengasih Sub-District, Kulonprogo Regency, DIY. Proc Internat Conf Sci Engin 1: 147-152. Research of manganese distribution was conducted in the village of Karangsari, Pengasih sub-district, Kulonprogo Regency, DIY which is the former area exploration and exploitation of manganese. The purpose of the research is known the value of relative conductivity and the distribution of manganese. The method used very low frequency tilt mode. The tools used 2 set of T-VLF BRGM (sensor and monitor) and the data processing software are Ms. Excel and KHFILT. T-VLF operated with 2 frequencies that are $19800 \mathrm{~Hz}$ from Australia and $22.200 \mathrm{~Hz}$ from Elbino Japan. The total lines are 6 lines with $75 \mathrm{~m}$ space. Distance between measured points is $15 \mathrm{~m}$, whereas line length is $300 \mathrm{~m}$. The parameters measured from VLF method are tilt (\%) and ellipticity (\%). The raw data VLF is processed by Ms Excel to obtain a tilt, ellipse, fraser graph vs distance and the RAE from Karous Hjelt filter. While the results of processed by KHFILT software is the equivalent current density contour map. Relative conductivity of area research are line $1(-10$ to 10$) \mathrm{mho} / \mathrm{m}$, line $2(-40$ to 30$) \mathrm{mho} / \mathrm{m}$, line $3(-20$ to 20$) \mathrm{mho} / \mathrm{m}$, line 4 (-30 to 10$) \mathrm{mho} / \mathrm{m}$, line $5(-40$ to 30$) \mathrm{mho} / \mathrm{m}$ and line $6(-30$ to 40$) \mathrm{mho} / \mathrm{m}$. The spread of manganese were in the high conductivity, toward west and east of research area with depth up to $45 \mathrm{~m}$.
\end{abstract}

Keywords: Conductivity, karangsari, manganese, tilt mode, VLF

\section{INTRODUCTION}

VLF method is one of the geophysical method that can be used to determine of rock conductivity. Since the 1960, the VLF-EM technique has been widely used for mineral exploration and groundwater prospecting (Telford, 1990). The sources of these EM fields are large radio transmitters used for submarine communication in the frequency range $10-30 \mathrm{kHz}$.

T-VLF measurement is to measure the electromagnetic fields in the path above the target. Primary wave are induces conductivity rock/ target so the target will bring up the secondary electromagnetic wave. The secondary electromagnetic field strength is proportional to conductivity of rock. By measuring the field strength in a certain direction indirectly can detect electrical conductivity of rock beneath it (Suyanto, 2011).

Development of technology and industry are need for mineral increases. One of them against manganese minerals. Manganese is very useful in industrial one of them for manufacture batteries. Karangsari Village, Pengasih Sub district, Kulonpogo Regency of DIY is one area that has the potential of natural resources in the form of manganese are quite potential. In the area has been done exploration of manganese based on geological information in the form of outcrops on the surface (Sudiyanto et al, 2011). However mining activities in the area have been stopped.

The purpose of the research is known the value of relative conductivity and the distribution of manganese.
Surveys were conducted using VLF method tilt mode because the morphology of the research area is a bumpy hilly region (Sudiyanto et al, 2011). T-VLF is a practical tool carried in the areas with difficult topography. In addition, the study area is included in the Sentolo Formation unit (Sudiyanto et al, 2011). Sentolo Formation consisting limestone and sandstone. The resistivity of limestone and sandstone is greater than manganese (Neibhigian, 1991). Resistivity and conductivity are inversely proportional so that manganese has greatest conductivity. Physics properties of manganese capable of conducting electrical current is in accordance with the physical parameters VLF method. Using VLF method in this research is an initial survey. It is expected that the VLF survey can provide information on the location of manganese distribution so that the follow up survey using other geophysical method can be more effective and efficient.

\section{Manganese}

Manganese is a hard metal and very fragile. Hard to melt, but easily oxidized. Manganese is reactive when pure, as the powder will burn in oxygen, react with water and dissolve in dilute acid. Manganese resembles iron but harder is a semiconductor material (Ansori, 2010).

\section{VLF Method}

Maxwell's equations which are the shape of the propagation of electromagnetic waves associated with the vector of the electric field and the magnetic field are: 


$$
\begin{aligned}
& \nabla \times \vec{E}=-\frac{\partial \vec{b}}{\partial t} \\
& \nabla \times \vec{H}=\vec{J}+\frac{\partial D}{\partial t}
\end{aligned}
$$

That is, $\vec{E}=$ electric field intensity $(\mathrm{V} / \mathrm{m}), \vec{H}=$ intensity of magnetization field $(\mathrm{A} / \mathrm{m}), \vec{B}=$ magnetic induction or flux intensity (Wb/m² or tesla), $\vec{D}=$ electric shift $\left(\mathrm{C} / \mathrm{m}^{2}\right)$ and $\vec{l}=$ current density $\left(\mathrm{A} / \mathrm{m}^{2}\right)$. With the additional tensor reduction relations will be obtained equation that simply relates to the field. If $\vec{E}$ and $\vec{H}$ fields are assumed only as an exponential function of time, obtained:

$$
\begin{aligned}
& \nabla^{2} \vec{E}=i \omega \mu \sigma \vec{E}-\omega^{2} \mu \varepsilon \vec{E} \\
& \nabla^{2} \vec{H}=i \omega \mu \sigma \vec{H}-\omega^{2} \mu \varepsilon \vec{H}
\end{aligned}
$$

$\varepsilon$ is dielectric permittivity dielectric $(\mathrm{F} / \mathrm{m}), \mu$ is magnetic permeability $(\mathrm{H} / \mathrm{m})$, and $\sigma$ electric conductivity $(\mathrm{mho} / \mathrm{m})$. The left shows the conduction current while the right side on the right of equation (3 and 4) shows the displacement current contribution (Telford, 1990).

The primary electromagnetic field of a radio transmitter having a vertical electrical field component $\mathrm{Ez}$ and a horizontal magnetic field component $\mathrm{Hy}$ perpendicular to the direction of propagation of the $\mathrm{X}$ axis. At a considerable distance from the transmitting antenna, Hy is primary electromagnetic field component can be considered as a horizontal wave as shown in Figure 1.

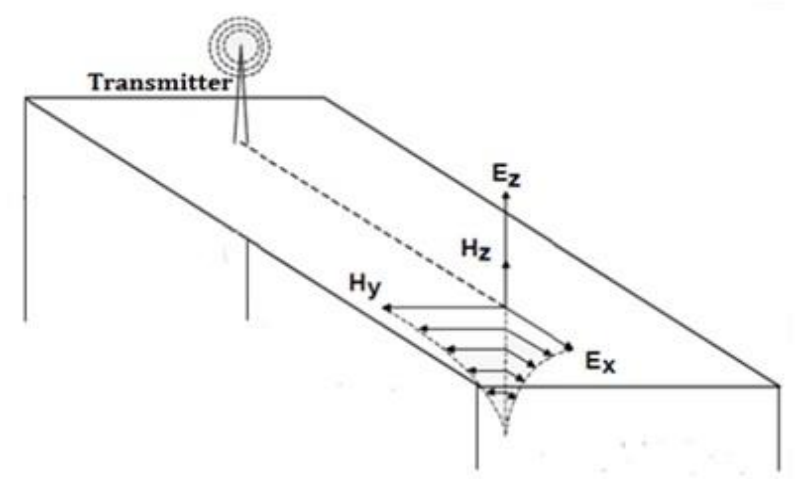

Figure 1. Primary electromagnetic field of transmitter (Sismanto et al, 2003).

If there is a conductive medium at subsurface, the magnetic field component of the primary electromagnetic wave are induces the medium to give rise to an induced current such as Figure 2.

Eddy current is caused by a VLF (Very Low Frequency) magnetic field on a more conductive soil that produces a secondary magnetic field with the same frequency and different phase.

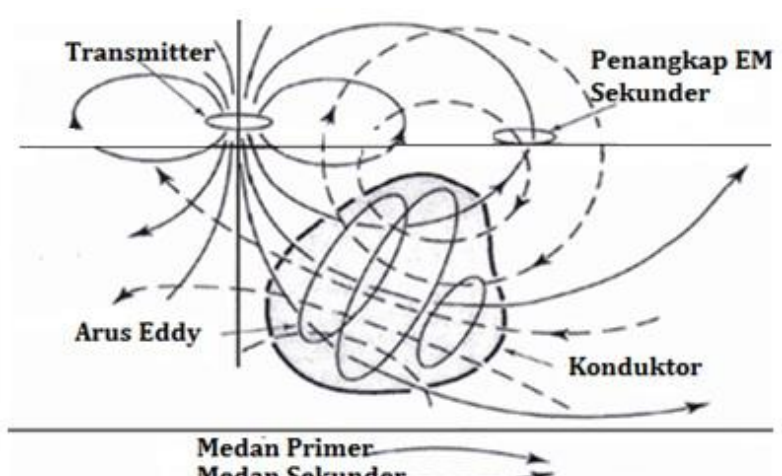

Figure 2. Electromagnetic waves for the VLF method (Suyanto and Yatini, 2003).

If the horizontal magnetic field is $\mathrm{Hx}$ and the vertical magnetic field is $\mathrm{Hz}$ then the magnitude of the tilt angle and the ellipticity is shown by Figure 3 whose magnitude is as follows (Telford, 1990):

$$
\begin{aligned}
\text { Tilt angle } & =\tan (2 \theta) \\
& =\frac{2\left[\frac{H_{z}}{H_{x}}\right] \cos \emptyset}{1-\left[\frac{H_{z}}{H_{x}}\right]^{2}} \cdot 100 \% \\
\text { Ellipticity } & =\varepsilon=\frac{b}{a} \\
& =\frac{H_{z} H_{x} \sin \emptyset}{\left[H_{z} \mathrm{e}^{\left.\mathrm{i} \phi_{\sin } \theta+H_{x} \cos \theta\right]}\right]^{\mathrm{s}}} \cdot 100 \%
\end{aligned}
$$

Extension:

$\mathrm{H}_{\mathrm{z}}$ = vertical magnetic field

$\mathrm{H}_{\mathrm{x}}=$ horizontal magnetic field

$\theta=$ angle between the major axis with the horizontal axis $(\mathrm{x})$

$\emptyset=$ phase difference between the primary and secondary EM waves

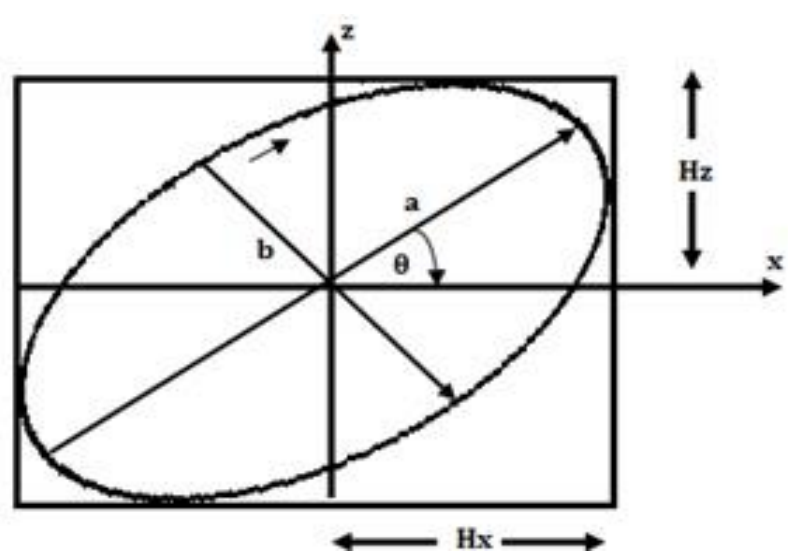

Figure 3. Parameter polarization ellipse. 


\section{MATERIALS AND METHODS}

The main tool used in the research is 1 set of T-VLF tool as receiver can be seen in figure 4 , dry battery as external power of sensor, compass and GPS for direction seeker.

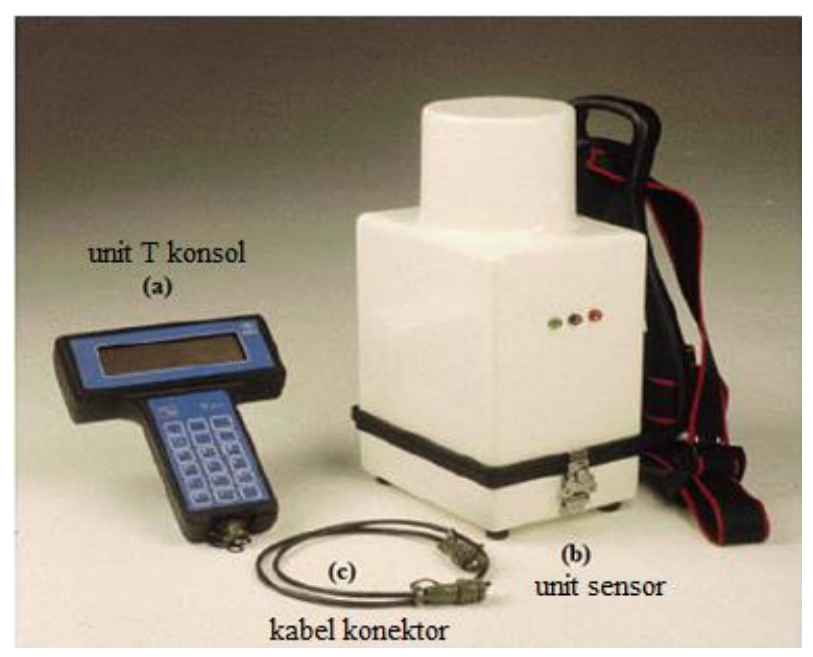

Figure 4. 1 set T-VLF BRGM.

Table 1. Parameter acquisition VLF.

\begin{tabular}{ll}
\hline Parameter & Parameter Value \\
\hline Total line & 6 line \\
Length of each line & $300 \mathrm{~m}$ \\
Measurement point & $10 \mathrm{~m}$ \\
Total point of each line & 21 point \\
Frequency & $19.800 \mathrm{~Hz}$ and $22.200 \mathrm{~Hz}$ \\
Parameter measured & Tilt and Ellipticity \\
\hline
\end{tabular}

Based on Table 1 and the VLF method rule tilt mode that strike target direction must be perpendicular to transmitter with angle tolerance of $45^{\circ}$. So the design survey in Karangsari Village, Pengasih Sub district, Kulonprogo Regency of DIY can be seen in Figure 5.

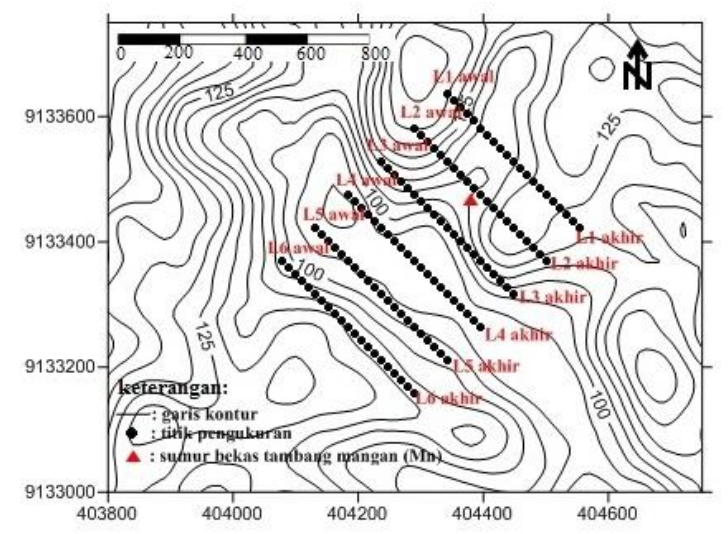

Figure 5. Design survey of the research area on topography map.

\section{RESULTS AND DISCUSSION}

Data acquisition was conducted in Karangsari Village, Pengasih Sub-district, Kulonprogo Regency of DIY. Actual point of measurement can be seen in Figure 6 . The absence of the measuring point with the survey design due to GPS error on track 1 and some points are in the steep terrain.

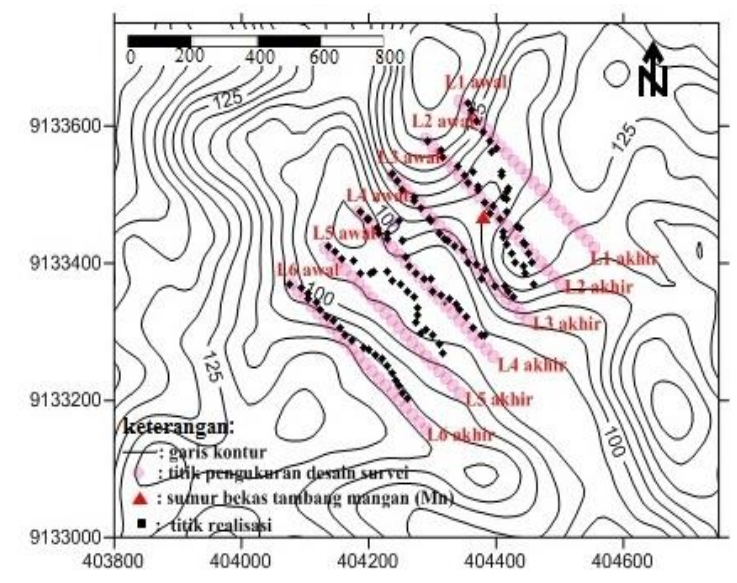

Figure 6. Measurement Realization Map.

T-VLF can work with 2 transmitter as comparison. In this research using NWC transmitter from Australian with frequency $19.800 \mathrm{~Hz}$ and NDT from Japan with frequency $22.200 \mathrm{~Hz}$. However on processing the data is selected only from NWC because NDT often disturbed in the field. Raw data obtained in the field are tilt (\%) and ellipticity (\%) which further using Ms. Excel to get graph of relation between tilt, ellipse vs distance. The pattern of intersection of tilted ellipse can be assumed to be a conductive area. Such direct interpretation is not recommended because the data is still saturated noise. Then tilt data though using fraser filter in Ms. Excel. The result is graph fraser Vs distance. The equation of fraser filter $=\left(M_{1}+M_{2}-M_{a}-M_{4}\right)$, where $M$ is tilt data from acquisition in the research area (fraser, 1969). Conductive zone is suspected to be under a fraser pellet. Interpretation of the fraser graph cannot determine the exact depth and distance of the anomaly so it must be correlated with the processing using the Karous Hjelt Filter to find the pseudo depth and the equivalent current density of each path (proportional to conductivity). Equation of Karous Hjelt filter is:

$$
\begin{aligned}
H_{0}= & 0.102 M_{1}-0.059 M_{2}+0.561 M_{3}-0.561 M_{5}+ \\
& 0.059 M_{6}-0.102 M_{7}
\end{aligned}
$$

Where $\mathrm{M}$ is data tilt from research area. Once to do this filter process then obtained by depth one spaces and multiples (Karous Hjelt, 1983). Then create an equivalent current density contour map to map the manganese distribution using KHFILT software which is then collated with tilt graph, ellipse, fraser vs distance to identify the target. The last step is slicing each depth 
to determine the direction of manganese spread of each depth.

Here is the result of correlation equivalent current density with the graph of tilt, ellipse and fraser of each track.

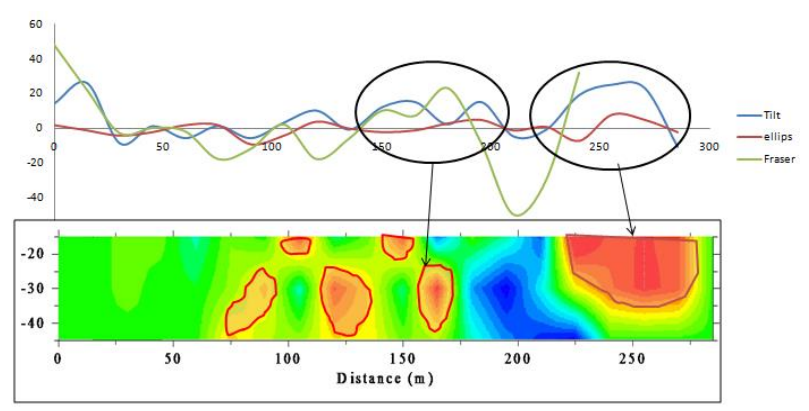

Figure 7. Correlation of fraser graph with contour map of RAE track 1.

Based on Figure 7 it is assumed that the conductive zone of potentially manganese is located at a distance of $50-175 \mathrm{~m}$ and $225-300 \mathrm{~m}$. This is because of there is correlation between the tilt, ellipse and fraser graph with the high value RAE (equivalent current density) contour map.

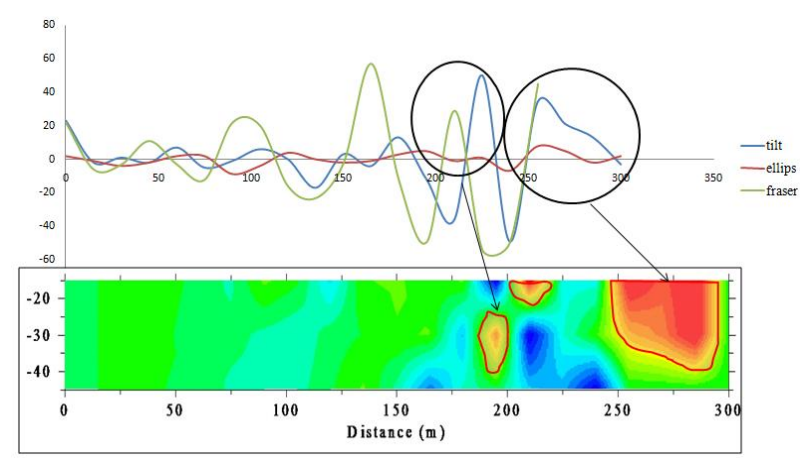

Figure 8. Correlation of fraser graph with contour map of RAE track 2.

Based on Figure 8 it is assumed that the conductive zone of potentially manganese is located at a distance of $200-225 \mathrm{~m}$ and $250-300 \mathrm{~m}$. This is because there is correlation between graphs with RAE contour maps.

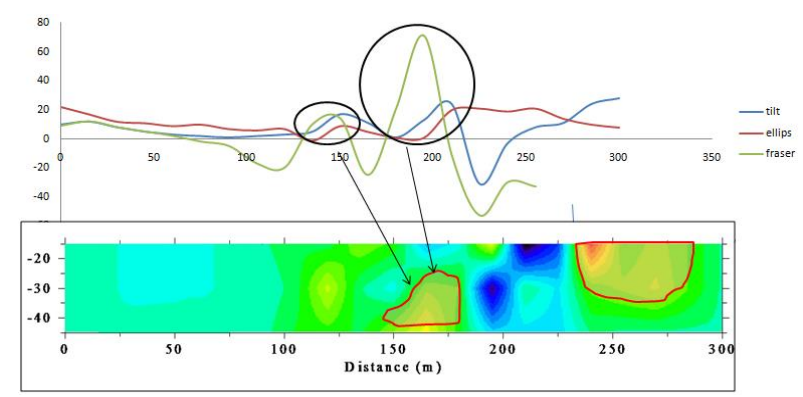

Figure 9. Correlation of fraser graph with contour map of RAE track 3 .

Based on Figure 9 it is assumed that the conductive zone of potentially manganese is located at a distance of $150-175 \mathrm{~m}$ and $250-300 \mathrm{~m}$. This shows from correlation of RAE contour map with the peak of the fraser graph.
At a distance of $225-250 \mathrm{~m}$ were found outcrop of manganese image 10 .

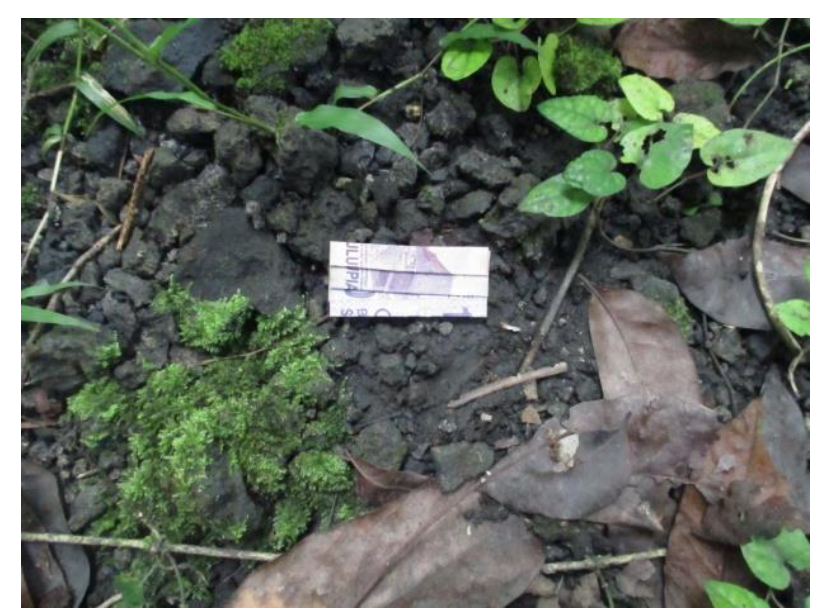

Figure 10. Manganese Outcrop Track 3 distance 225-250 m.

Based on Figure 11 it is assumed that the conductive zone of potentially manganese is located at a distance of $50-100 \mathrm{~m}$ and at a distance of $225-275 \mathrm{~m}$. This is indicated by the correlation of the peak of the fraser graph and the RAE contour map. At a distance of 20 meters from the meter measurement point to 45-60 track 4 found the tunnel of manganese manganese can be seen in Figure 12 continuously to the east.

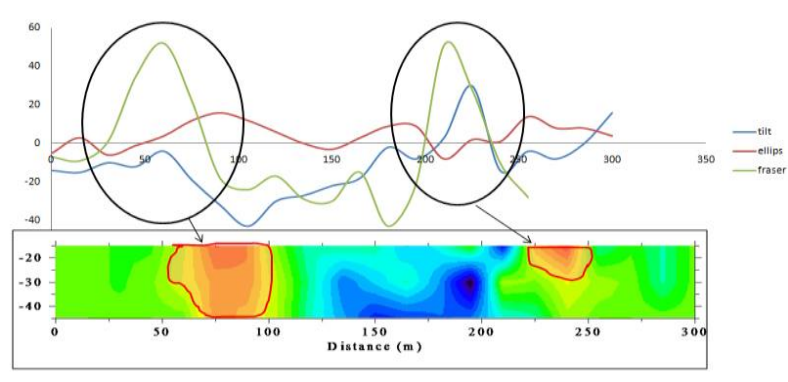

Figure 11. Correlation of fraser graph with contour map of RAE track 4.

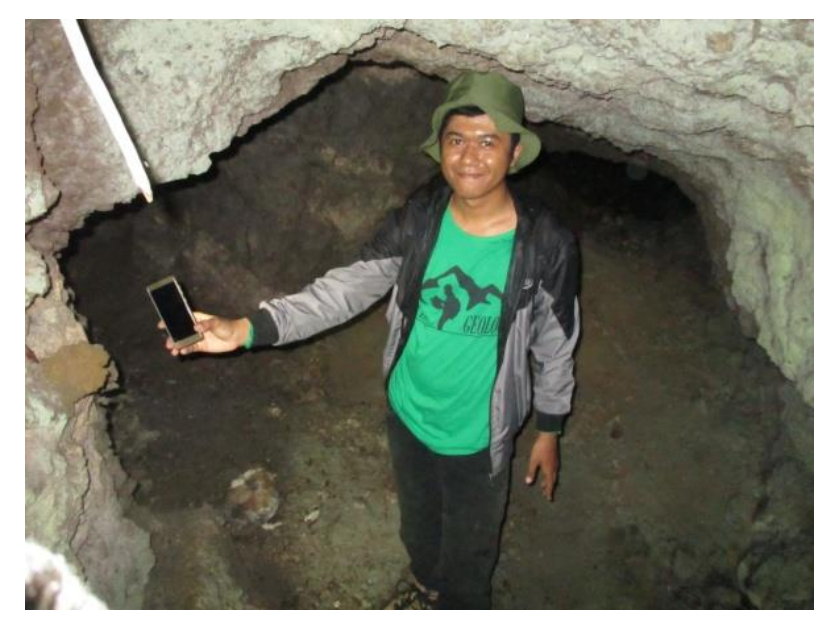

Figure 12. Tunnel of manganese mine. 
Based on Figure 13 it is assumed that the conductive zone of potentially manganese is located at a distance of $60-150 \mathrm{~m}$. This is indicated by the correlation of the peak of the fraser graph with the RAE contour map. And there is manganese land at a distance of $65-120 \mathrm{~m}$ can be seen in Figure 14.

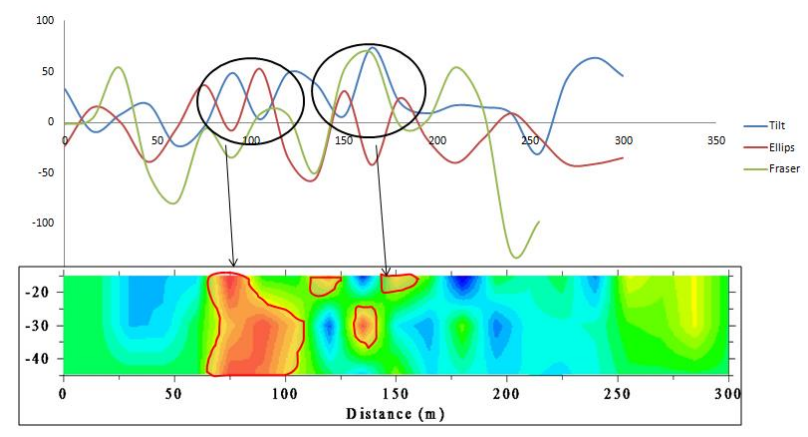

Figure 13. Correlation of fraser graph with contour map of RAE track 5.

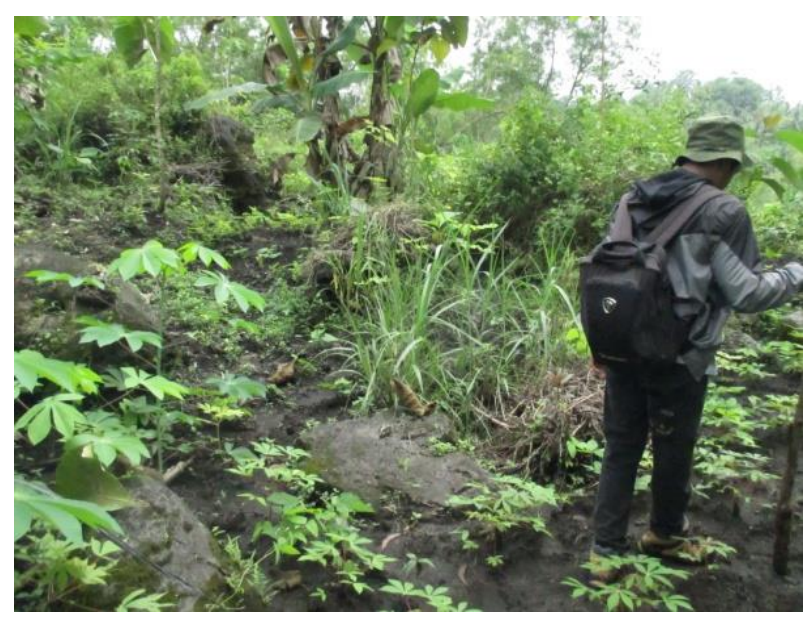

Figure 14. Location of the former manganese mine track $5(65-120 \mathrm{~m})$.

Based on Figure 15 it is assumed that the conductive zone of potentially manganese is at a distance of 175$225 \mathrm{~m}$. This is shown by the correlation of the peak of the fraser graph with the result of the RAE contour map showing the high value at that distance.

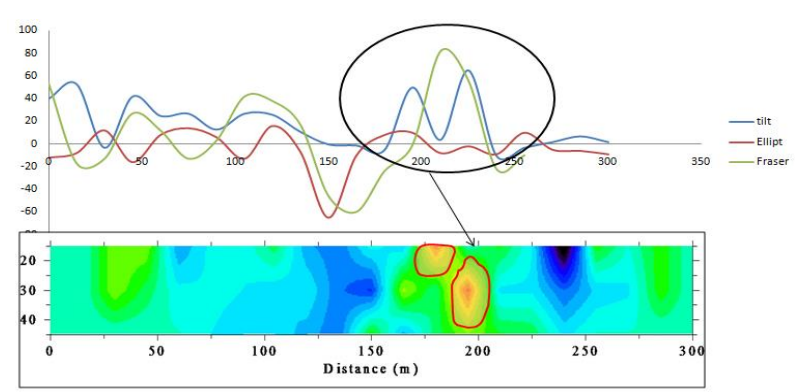

Figure 15. Correlation of fraser graph with contour map of RAE track 6.

After doing the correlation between graph with contour map of RAE then sclicing per depth using surfer software can be seen in figure 16 .
Based on figure 16 is estimated manganese distribution in the west and east of the research area. In the western part of the study manganese distribution is seen from the topography is in the hill to the valley while in the eastern part of the study suspended manganese distribution is in the valley to the hill. It is estimated that the manganese potential in the east of the study is located up to $45 \mathrm{~m}$ depth, while in the western part of the study it is estimated that the biggest potential manganese is up to $30 \mathrm{~m}$ depth, at a depth of $45 \mathrm{~m}$ There is still the potential of manganese but smaller than in the depth of 15 and $30 \mathrm{~m}$.

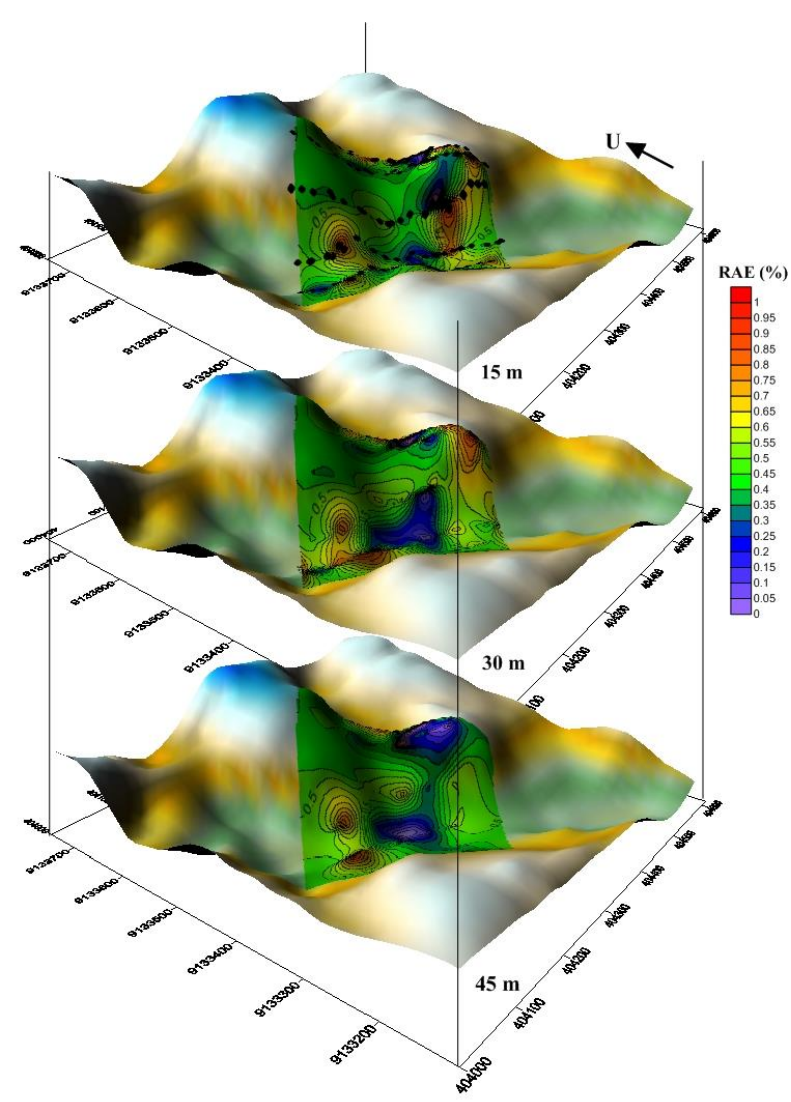

Figure 16. Map of each incision in the village of Karangsari, District Pengasih, Kulonprogo Regency, DIY.

\section{CONCLUSIONS}

Based on VLF survey, it is known that the equivalent current density value of each track is relative to the research area. In the track 1 (-10 to 10$)$ mho / m, track 2 (-40 to 30) mho / m, track 3 (-20 to 20) mho / m, track 4 (-30 to 10$) \mathrm{mho} / \mathrm{m}$, track 5 (-40 to 30$) \mathrm{mho} / \mathrm{m}$ and track $6(-30$ to 40$) \mathrm{mho} / \mathrm{m}$. The high conductivity in the area of research is thought to be a manganese that spreads in the west and east of the study area. With a depth of up to $45 \mathrm{~m}$ in the east and $30 \mathrm{~m}$ in the west.

\section{ACKNOWLEDGEMENTS}

Thank you to the local government and villagers of Karangsari Village, Pengasih Subdistrict, Kulonprogo 
Regency of DIY with the permission given to do the research. Thank you for the VLF acquisition team and all the sessions of this paper.

\section{REFERENCES}

Ansori, C. 2010. Potensi Dan Genesis Mangan Di Kawasan Kars Gombong Selatan Berdasarkan Penelitian Geologi Lapangan, Analisis Data Induksi Polarisasi Dan Kimia Mineral. Buletin Sumber Daya Geologi Volume 5 Nomor 2.

Sudiyanto, A., Widodo, P., Agung, T., Cahyadi dan Pratiwi. 2011. Analisis Kelayakan Ekonomi Rencana Penambangan Bijih Mangan Di Daerah Karangsari Kabupaten KulonprogoDIY. Prosiding TPT XX Perhapi, -. pp. 289-301. ISSN 978979-8826-20-7.

Fraser D.C. 1969. Contouring of VLF-EM data. Geophysics 34,958-967.

Karous, M dan S.E, Hjelt. 1983. Linear filtering of VLF dip-angle measurements. Geophysical Prospecting 31, 782-794.
Nebighian, M.N., 1991. Electromagnetic Methods In Applied Geophysics. In J. D. Corbett, ed. Investigation in Geophysics. Tusla, Oklahoma: Society of exploration Geophysics, pp. 521-640.

Sismanto, Hartantyo, E., Sudarmaji, Nukman, M., Suryanto dan W., 2003. Tanggapan Gelombang Elektromagnetik Frekuensi Rendah (VLF) dari Sungai Bawah Tanah: Sebuah Uji Coba Metode VLF di Sekitar Goa Bribin, Gunung Kidul, Yogyakarta. Jurnal Fisika Indonesia, VII (20), pp.31-42.

Suyanto, Imam. 2007. Analisa Data VLF (Very Low Frequency) Untuk Mengetahui Kemenerusan Pipa Gas Bawah Permukaan di Gresik Jawa Timur. Jurnal Fisika Indonesia, No: 34, Vol.XI ISSN: 1410-2994.Hal.169-179.

Suyanto, Imam dan Yatini. 2011. Data Analysis of VLF (Very Low Frequency) To Determined Continuum Underground Gas Pipelines At Gresik, East Java. JIK Tek-min. No: 3, Vol 24 ISSN 0854-2554.

Telford, W.M. 1990. Applied Geophysics Second Edition. Cambridge University. 